\title{
Drogas que reducen el nivel de glucosa también reducen el riesgo cardiovascular"
}

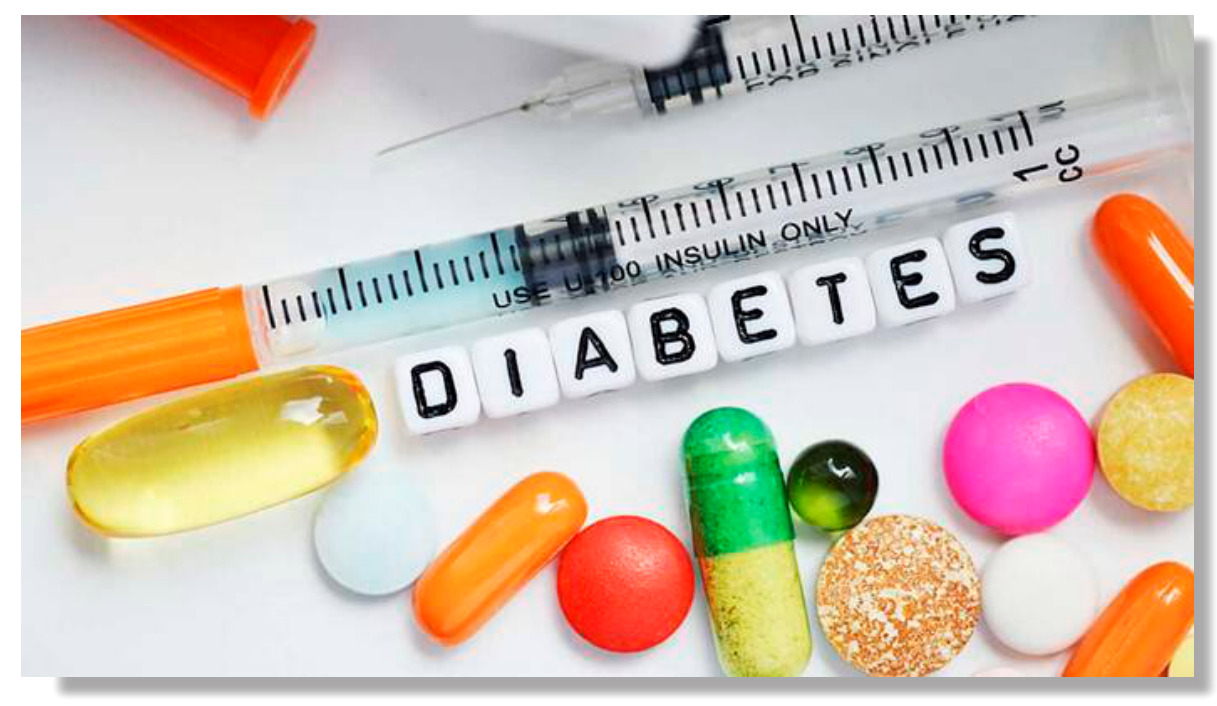

La diabetes afecta a más de 450 millones de personas en el mundo y tiene una prevalencia global del $9.3 \%$. La diabetes tipo 2 constituye entre el 90 a $95 \%$ de los casos.

Las principales complicaciones de la diabetes son microvasculares (retinopatía, neuropatíia y nefropatía).

Las macrovasculares son: enfermedad coronaria, enfermedad vascular periférica y enfermedad cerebrovascular.

Se recomienda un nivel de hemoglobina glicosilada de $6.5 \%$ a $7.0 \%$. Evaluar el status cardiovascular y los factores de riesgo es crítico para seleccionar nuevas drogas para reducir el riesgo cardiovascular.
Medicamentos que han demostrado eficiencia son los agonistas del GLP 1 o agonistas del receptor de sodio en el riñón.

El riesgo de los pacientes diabéticos es igual al de los pacientes que ya han tenido un infarto.

Se están utilizando agentes orales combinados con insulina. Lo más importante es evaluar el riesgo cardiovascular antes de iniciar cualquier tratamiento.

Evaluar siempre el costo del tratamiento que sea factible para el paciente.

Rolando Calderón-Velasco

\footnotetext{
1. Kelyan RR. División de Endocrinología Johns Hopkins

University. N Engl J Med. 2021;384:1248-1260.
}

Citar como: Calderón-Velasco R. Revista de Revistas. Drogas que reducen el nivel de glucosa también reducen el riesgo cardiovascular. Diagnóstico(Lima). 2021;60(1):65.

DOI: 10.33734/diagnostico.v60i1.271

Correspondencia: Rolando Calderón Velasco. Correo electrónico: rocalve@gmail.com 